\title{
46. Decrease in the Amount of NAD and Increase in the Activity of Poly (ADP-Ribose) Synthetase in Chicken Dystrophic Muscle
}

\author{
By Akira Yoshikawa*) and Tomoh Masaki*),**) \\ (Communicated by Setsuro EBASHI, M. J. A., June 14, 1983)
}

A failure of normal development in dystrophic muscle, i.e. failure in completing the transition from juvenile to mature type of various proteins, was observed by many investigators. ${ }^{1)-7)}$ For example immaturation of isozyme pattern of lactic dehydrogenase, ${ }^{1)-4)}$ myosin and tropomyosin ${ }^{5), 6)}$ in dystrophic muscle has been precisely described.

Among many factors which have an influence on the development and differentiation of muscle cell, we focused our attention on cellular NAD levels and the activity of poly (ADP-ribose) synthetase of muscle. Intracellular NAD levels have been pointed out to play a role in the control of the commitment into specific phenotype either in vivo or in cell cultures. ${ }^{8)}$ The activity of poly (ADP-ribose) synthetase, which converts NAD into poly (ADP-ribose) with the excision of nicotinamide, ${ }^{9)}$ was also shown to decrease slightly during later expressional events related to muscle development. ${ }^{10}$ )

We describe here the change in the NAD levels and the activity of poly(ADP-ribose) synthetase in both normal and dystrophic muscle during development.

Materials and methods. NAD, NADH, and alcohol dehydrogenase $(\mathrm{ADH})$ were purchased from Boehringer Mannheim. DNA (type VII) was purchased from Sigma Chemical Co., Ltd. (Adenine2,8- $\left.{ }^{3} \mathrm{H}\right)$ NAD was purchased from New England Nuclear Corp.

Fertilized eggs of dystrophic chickens (New Hampshire strain, line 413) and normal chickens (New Hampshire strain, line 412) were obtained from the Muscular Dystrophy Research Group of Japan.

Extraction of NAD and measurement of NAD concentration were carried out as described by Klingenberg. ${ }^{11)}$

Extraction of DNA and measurement of DNA concentration were carried out as described by Fleck. ${ }^{12}$ )

\footnotetext{
*) Tokyo Metropolitan Institute of Medical Sciences, 3-18-22, Honkomagome, Bunkyo-ku, Tokyo 113, Japan.

**) Institute of Basic Medical Sciences, University of Tsukuba, Ibaraki 305, Japan.
} 
Muscle nuclei were prepared as described by Chauveau ${ }^{13)}$ with some modifications. Muscles were homogenized with Waring blendor in 3 volumes $(\mathrm{w} / \mathrm{v})$ of buffer A $(0.1 \mathrm{M} \mathrm{KCl,} 20 \mathrm{mM}$ Tris-HCl (pH 7.4), $10 \mathrm{mM} \mathrm{MgCl}_{2}, 5 \mathrm{mM} \beta$-mercaptoethanol, $20 \mathrm{mM} \mathrm{Na}{ }_{4} \mathrm{P}_{2} \mathrm{O}_{7}$ and $0.25 \mathrm{M}$ sucrose). Homogenates were layered over the discontinuous sucrose density gradient consisting of $8 \mathrm{ml}$ of $2.1 \mathrm{M}$ and $8 \mathrm{ml}$ of $1.8 \mathrm{M}$ sucrose. The nuclei were then sedimented by centrifugation for $30 \mathrm{~min}$ in a Beckman SW27 rotor at $18,000 \mathrm{rpm}$. The nuclei were suspended in a buffer $\mathrm{A}$ without $\mathrm{Na}_{4} \mathrm{P}_{2} \mathrm{O}_{7}$ and stored in a deep freezer $\left(-80^{\circ} \mathrm{C}\right)$.

The activity of poly (ADP-ribose) synthetase was measured as described by Miwa. ${ }^{14)}$

Results and discussion. On the basis of muscle wet weight, NAD content in the breast muscle increases proportionally to the growth, especially in the first week after hatching (Table I). The NAD content of dystrophic breast muscle is slightly lower than

Table I. NAD concentration in normal and dystrophic muscle

\begin{tabular}{llcccc}
\hline & $\begin{array}{c}\text { 20-day-old } \\
\text { embryo (8) }\end{array}$ & $\begin{array}{c}\text { 1-week-old } \\
(8)\end{array}$ & $\begin{array}{c}\text { 2-week-old } \\
(5)\end{array}$ & $\begin{array}{c}\text { 5-week-old } \\
(4)\end{array}$ & $\begin{array}{c}\text { 8-week-old } \\
(4)\end{array}$ \\
\hline Nor & $0.193 \pm 0.008$ & $0.765 \pm 0.036$ & $0.932 \pm 0.060$ & $1.183 \pm 0.073$ & $1.268 \pm 0.030$ \\
Dys & $0.197 \pm 0.009$ & $0.578 \pm 0.042 *$ & $0.828 \pm 0.065$ & $0.968 \pm 0.057$ & $1.148 \pm 0.055$ \\
\hline
\end{tabular}

NAD concentration was determined by the spectrophotometric procedure using $\mathrm{ADH}$ as described by Klingenberg. ${ }^{11)}$ Muscles of 2 to 3 birds were pooled in the case of embryonic or 1-week-old samples. Whole breast muscles were used to avoid the risks of uneven distribution of NAD in muscle. The results were calculated on the basis of $\mu$ mol NAD per $g$ wet weight of muscle. Values are means \pm standard errors. Number of samples are shown in parentheses. * Statistically significant $(\mathrm{P}<0.05)$.

that of normal muscle in all stages except in 20-day-old embryos, but no statistical significance in the NAD content between normal and dystrophic muscle is observed except in one-week-old chickens (Table I). However, if NAD content is expressed as DNA, the ratio of NAD content of dystrophic to normal muscle decreases more than the value shown above in every stage, because the DNA content of dystrophic muscle is higher than that of normal muscle before 8week-old after hatching except for 20-day-old embryos (Table II). Decrease of DNA content of dystrophic muscle at 1-year-old may be due to the decrease in number of nuclei in a given amount of muscle, because the atrophic muscle contains larger amount of fat tissue.

The difference in the NAD concentration between normal and dystrophic muscle suggests changes in the amount of poly (ADP-ribose) and poly(ADP-ribose) synthetase activity in dystrophic muscle. ${ }^{10}$ ) 
As shown in Fig. 1, the activity of poly (ADP-ribose) synthetase in dystrophic muscle increases in both nuclei from 2-week-old (Fig. 1A) and from 5-week-old chicken (Fig. 1B) when compared to normal muscle. However, no difference in the poly (ADP-ribose) synthetase activity between normal and dystrophic muscle from 20-day-old embryo is observed (data is not shown). Equal volumes of the samples of normal and dystrophic breast muscle were mixed. The resulting activity of the mixture showed the intermediate between both samples. This fact means that increase in the activity of poly

Table II. DNA concentration in normal and dystrophic muscle

\begin{tabular}{lcccccc}
\hline $\begin{array}{c}20 \text {-day- } \\
\text { old } \\
\text { embryo } \\
(5)\end{array}$ & $\begin{array}{c}\text { 1-week- } \\
\text { old } \\
(6)\end{array}$ & $\begin{array}{c}\text { 2-week- } \\
\text { old } \\
(5)\end{array}$ & $\begin{array}{c}\text { 5-week- } \\
\text { old } \\
(4)\end{array}$ & $\begin{array}{c}\text { 8-week- } \\
\text { old } \\
(4)\end{array}$ & $\begin{array}{c}\text { 1-year- } \\
\text { old } \\
(4)\end{array}$ \\
\hline Nor & $3.34 \pm 0.09$ & $1.63 \pm 0.08$ & $1.05 \pm 0.09$ & $1.01 \pm 0.06$ & $0.94 \pm 0.16$ & $0.99 \pm 0.07$ \\
Dys & $3.27 \pm 0.06$ & $1.93 \pm 0.08^{*}$ & $1.52 \pm 0.14^{*}$ & $1.42 \pm 0.04^{*}$ & $1.33 \pm 0.13$ & $0.43 \pm 0.04^{*}$ \\
\hline
\end{tabular}

DNA concentration was determined as described in Materials and methods. The results were calculated on the basis of $\mathrm{mg}$ DNA per $\mathrm{g}$ wet weight of muscle. Values are means \pm standard errors. Number of samples are shown in parentheses. * Statistically significant $(\mathrm{P}<0.05)$.

(A)

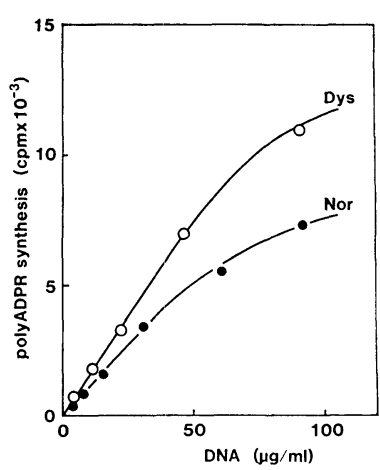

(B)

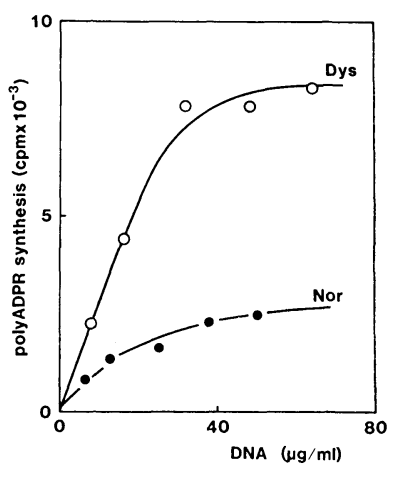

Fig. 1. The activity of poly (ADP-ribose) synthetase of normal and dystrophic chicken breast muscle nuclei. Poly(ADP-ribose) synthetase activity was assayed in a reaction mixture which contained $12.5 \mu \mathrm{mol}$ Tris- $\mathrm{HCl}$ $(\mathrm{pH} 8.0), 3.1 \mu \mathrm{mol} \mathrm{MgCl}_{2}, 0.1 \mu \mathrm{mol} \mathrm{DTT}, 4 \mu \mathrm{l}$ of $\left(\mathrm{Ad}-2,8{ }^{3} \mathrm{H}\right) \mathrm{NAD}(3.4 \mathrm{Ci} /$ $\mathrm{mmol}, 0.1 \mathrm{mCi} / \mathrm{ml}, \mathrm{NEN}$ ), and various amounts of chicken muscle nuclei, in a total volume of $0.125 \mathrm{ml}$. The reaction was at $25^{\circ} \mathrm{C}$ for $15 \mathrm{~min}$ and terminated by the addition of $5 \%$ TCA including $1 \%$ pyrophosphate. The precipitate was washed twice with $5 \%$ TCA and collected on a glass microfibre paper (Whatman, GF/C). The paper was washed with ethanol and dried. The radioactivity was determined with a Beckman scintillation counter. Amount of DNA on abscissa is given in $\mu \mathrm{g} / \mathrm{ml}$ reaction system. A : Nuclei from 2-weeks-old chicken breast muscle. B : Nuclei from 5-week-old chicken breast muscle. •, normal; O, dystrophy. 
(ADP-ribose) synthetase from dystrophic muscles may not be due to the absence of inhibitors or presence of activators of poly (ADPribose) synthetase.

Poly-ADP-ribosylation is one of the post-translational modifications of nuclear proteins in eukaryotes ${ }^{9)}$ and has been suggested to be involved in the regulation of various nuclear functions, such as DNA synthesis, histone function, cell differentiation and DNA repair. ${ }^{10), 15)-19)}$ The increase in the activity of poly(ADP-ribose) synthetase in dystrophic muscle suggests following possibilities. Firstly, it means delay or failure of differentiation of muscle cell. It is reported that during the differentiation, the poly (ADP-ribose) synthetase activity decreases in Friend erythroleukemia cells. ${ }^{20}$ ) In differentiation of chicken limb muscle, poly (ADP-ribose) level is also reported to decrease after 12-day-old embryo. ${ }^{10)}$ The conversion of isoform pattern of proteins from juvenile to adult type in normal muscles is completed within one week after hatching. ${ }^{5)}$ Therefore, a possibility is suggested that dystrophic muscle fails in this terminal differentiation. Secondly, dystrophic muscle may suffer from DNA damage. For it is reported that the increase in the poly (ADPribose) synthetase activity is accompanied by the DNA repair. ${ }^{17}{ }^{-19}$ ) However, there is no report, so far, to support the second possibility in dystrophic muscle. Any way, no difference in DNA content, NAD content, and poly(ADP-ribose) synthetase activity between normal and dystrophic chicken of 20-day-old embryo suggests that the failure in terminal differentiation or the damage to DNA may occur just after hatching.

Acknowledgement. This study was supported in part by a grant from the Ministry of Health and Welfare, Japan.

\section{References}

1) Kaplan, N. O., and Cahn, R. D. (1962) : Biochemistry, 48, 2123-2130.

2) Emery, A. E. H. (1964) : Nature, 201, 1044-1045.

3) Pearson, C. M. et al. (1965): Amer. J. Med., 39, 91-97.

4) Tsvetanova, E., and Ognianov, M. (1967): Clin. Chim. Acta, 18, 87-88.

5) Obinata, T., Ohmuro, T. H., and Matsuda, R. (1980): FEBS Lett., 120, 195-198.

6) Takeda, S., and Nonomura, Y. (1980): Biomed. Res., 1, 176-179.

7) Schapira, F., Dreyfus, J. C., and Allard, D. (1968) : Clin. Chim. Acta, 20, 439-447.

8) Caplan, A. I., and Rosenberg, M. J. (1975) : Proc. Nat. Acad. Sci. U.S., 72, 1852-1957.

9) Nishizuka, Y. et al. (1967): J. Biol. Chem., 242, 3164-3171.

10) Caplan, A. I. et al. (1979): Dev. Biol., 72, 102-109.

11) Klingenberg, M. (1974) : Methods of Enzymatic Analysis (ed. Bergmeyer, H. U.). vol. IV. Academic Press, N.Y., pp. 2045-2072. 
12) Fleck, A., and Munro, H. N. (1962): Biochim. Biophys. Acta, 55, 571-583.

13) Miwa, M., and Sugimura, T. (1975): Seikagaku Jikken Koza (eds. Imahori, K., Kaziro, Y., and Nishimura, S.). vol. 7, Tokyo Kagaku Doujin, Tokyo. pp. 528-543 (in Japanese).

14) Chauveau, J., Moulé, Y., and Rouiller, C. (1956) : Exptl. Cell Res., I1, 317-321.

15) Burzio, L., and Koide, S. S. (1971): Biochem. Biophys. Res. Commun., 42, 1185-1190.

16) Roberts, J. H., Stark, R., and Smulson, M. (1973) : ibid., 52, 43-50.

17) Miller, E. G. (1975) : Biochim. Biophys. Acta, 395, 191-200.

18) Durkacz, B. W. et al. (1980): Nature, 283, 593-596.

19) Juarez-Salinas, H., Sims, J. L., and Jacobson, M. K. (1980) : Nature, 282, 740-741.

20) Terada, M. et al. (1979) : Proc. Nat. Acad. Sci. U.S., 76, 6411-6414. 